\title{
Content of Fecal Coliform Bacteria as an Indicator of Water Quality in the Sungai Jingah, Banjarmasin City
}

\author{
Aulia Safitri ${ }^{1 *}$ Deasy Arisanty ${ }^{1}$ Aswin Nur Saputra ${ }^{1}$ Nasruddin $^{2}$
}

\author{
${ }^{1}$ Department of Geography Education, Faculty of Teacher Training and Education, Universitas Lambung Mangkurat, \\ Banjarmasin 70123, Indonesia \\ ${ }^{2}$ Department of Geography, Faculty of Social and Political Science, Universitas Lambung Mangkurat, Banjarmasin \\ 70123, Indonesia \\ ${ }^{*}$ Corresponding author. E-mail: safitria726@gmail.com
}

\begin{abstract}
Sungai Jingah water quality based on the number of Fecal Coliform Bacteria, TDS (Total Dissolved Solids), BOD (Biological Oxygen Demand) and pH compared to South Kalimantan Governor Regulation No.005 of 2007, and the relationship between Fecal Coliform and Water Quality includes TDS, BOD, and pH. This type of research is descriptive quantitative. The data analysis technique used is a laboratory test to test the parameters of Fecal Coliform, BOD, pH and TDS, while the product moment correlation analysis is to determine the relationship between Fecal Coliform and water quality from chemical and physical parameters. The results showed that the amount of Fecal Coliform bacteria contained during tides and high tides in the Sungai Jingah was high. The content of Fecal Coliform at low tide and high tide in Sungai Jingah compared to Governor Regulation No. 5 Year 2007 is the average being in class IV (>2000). The BOD content of Sungai Jingah varies from low to quite high. The $\mathrm{pH}$ content is in class II (6-7) which is included at low levels. Social research was conducted on people who live on the banks of the Sungai Jingah in Banjarmasin City, most of the people have not used river water as a source of water for their daily needs, namely for drinking water and toilets.
\end{abstract}

Keywords: Fecal coliform, Sungai Jingah, waters.

\section{INTRODUCTION}

Water cannot be replaced with other substances or objects, water is everything for living things in the world [9]. Industrial, agricultural, livestock and household waste disposal activities pollute rivers which are the source of community life so that the quality of river water has decreased [1].

The city in Indonesia that makes the river the source of life for the surrounding community is Banjarmasin. The capital of South Kalimantan Province is Banjarmasin City with an area of $72.67 \mathrm{Km}^{2}$. The growing industrial development and population growth in Banjarmasin City, directly or indirectly, can have a negative impact that affects the environmental conditions in Banjarmasin City, namely a decrease in the quality of the environment, especially the quality of river water flowing in Banjarmasin City [2].

The existence of domestic waste in the waters is one of the causes of water pollution [3]. The most dangerous part of domestic waste is pathogenic microorganisms that are contained in feces because they can transmit various diseases when they enter the human body. There are at least 37 types of water-borne diseases including diarrhea [6]. Coliform bacteria are a group of intestinal bacteria, which live in the human digestive tract. Coliform bacteria are indicators of the presence of other pathogenic bacteria. The determination of Coliform bacteria is an indicator of pollution because the number of colonies is definitely positively correlated with the presence of pathogenic bacteria. In addition, detecting Coliform is much cheaper, faster, and simpler than detecting other pathogenic bacteria. Coliform is an indicator of water quality. The less Coliform content, the better the water quality [5].

Coliform bacteria can be divided into two parts, namely faecal Coliform, for example E. Coli is a bacteria that comes from animal or human feces [6]. Non-faecal coliforms such as Enterrobacter aeroginosa are usually found in dead animals or humans [10]. E. Coli bacteria are microorganisms that are used as indicators to test for water contamination by feces [8].

\section{METHOD}

Sungai Jingah is located at latitude $3^{\circ} 17^{\prime} 38.22^{\prime}$ latitude to $114^{\circ} 36^{\prime} 14.73$ "east longitude. Banjarmasin city itself is located at latitude $3^{\circ} 16^{\prime} 46^{\prime \prime} \mathrm{SL}$ to $3^{\circ} 22^{\prime} 54^{\prime \prime} \mathrm{SL}$ and $114^{\mathrm{O}} 31^{\prime} 40^{\prime \prime}$ EL to $114^{\mathrm{O}} 39^{\prime} 55^{\prime \prime}$ EL [4].

This research is descriptive quantitative in nature. The data analysis technique used is a laboratory test that aims to test the bacterial content of Fecal Coliform, BO, pH, and TDS, while determining the relationship between Fecal Coliform and BOD, $\mathrm{pH}$, and TDS using Product Moment correlation analysis. Primary data used were laboratory test results, while secondary data used were Diarrhea Case Data for South Kalimantan Province, Diarrhea Case Data for 
Banjarmasin City, data from the Central Statistics Agency (BPS), journals, books, etc.

\section{RESULT AND DISCUSSION}

Total content of Fecal Coliform Bacteria in segment IVB $(2400 / 100 \mathrm{ml})$, segment VB $(110 / 100 \mathrm{ml})$, segment IA (2400/100 ml), and segment IIB (2400/100 ml). Laboratory test data for Sungai Jingah water samples at low tide in segments IVB, IA, and IIB show a relatively high number of Fecal Coliform Bacteria. Laboratory test results data for Sungai Jingah water samples at high tide show all segments in the Sungai Jingah contain bacteria High Fecal Coliform. Total content of Fecal Coliform Bacteria in segment IVB $(2400 / 100 \mathrm{ml})$, segment VB $(2400 / 100 \mathrm{ml})$, segment IA $(2400 / 100 \mathrm{ml})$, and segment IIB $(2400 / 100 \mathrm{ml})$.

Almost all segments in the Sungai Jingah are in class IV ( $>$ 2000) at high and low tide, except for the VB segment at low tide which is classified into class II. The amount of Fecal Coliform Bacteria during the ebb and flow of tides in segment IVB is $(2400 / 100 \mathrm{ml})$, at low tide of segment VB is $(110 / 100 \mathrm{ml})$, then at high tide is $(2400 / 100 \mathrm{ml})$, at times of ups and downs, $x$ and the ups and downs of segment IA are $(2400 / 100 \mathrm{ml})$, and at the current low and high tide in segment IIB is $(2400 / 100 \mathrm{ml})$. Laboratory test data for Sungai Jingah water samples at low tide and high tide in segments IVB, VB, IA, and IIB indicate a relatively high number of Fecal Coliform Bacteria. Based on the Regulation of the Governor of South Kalimantan Number 5 of 2007 concerning Designation and Quality Standards for River Water. Water that is included in the level IV category cannot be used for drinking water and for other activities because it has been heavily polluted. The results of the Sungai Jingah Water Laboratory Test in segment VB at low tide showed a low number of Fecal Coliform Bacteria and was included in the level II category where this water cannot be used for drinking water but can still be used for other purposes such as irrigating crops.

\subsection{BOD (Biological Oxygen Demand)}

The content of BOD (Biological Oxygen Demand) in Sungai Jingah shows class differences in several segments. Total tidal content of BOD (Biological Oxygen Demand) in segment IVB $(1.1 \mathrm{mg} / 1)$, segment VB $(1.6 \mathrm{mg} / \mathrm{l})$, segment IA $(3.5 \mathrm{mg} / \mathrm{l})$ and segment IIB $(3 \mathrm{mg} / \mathrm{l})$. Laboratory test results show that the content of BOD (Biological Oxygen Demand) at low tide enters class I for segment IVB and VB, class II for segment IIB then class III for segment IA means that if you look at the content of BOD (Biological Oxygen Demand) contained in Sungai Jingah is still low, so the water quality from chemical parameters is still good. The BOD (Biological Oxygen Demand) content of Sungai Jingah at high tide all segments are in class I (2). In the IVB segment $(2 \mathrm{mg} / \mathrm{l})$, VB segment $(1.9 \mathrm{mg} / \mathrm{l})$, segment IA $(1.7 \mathrm{mg} / \mathrm{l})$, and segment IIB $(1.5 \mathrm{mg} / \mathrm{l})$. Based on the Regulation of the Governor of South Kalimantan Number 5 of 2007 concerning Designation and Quality Standards for River Water, the content of BOD (Biological Oxygen Demand) in the Sungai Jingah is in the class I category with good water quality.

\section{$3.2 \mathrm{pH}$}

The $\mathrm{pH}$ content in Sungai Jingah at low tide is in segment IVB (6.9), segment VB (6.9), segment IA (6.8), and segment IIB (6.8). The $\mathrm{pH}$ content at high tide increases in segment IV (6.8), segment VB (6.8), segment IA (6.7), and segment IIB (6.7). Based on the Regulation of the Governor of South Kalimantan Number 5 of 2007, the pH content in the Sungai Jingah at low tide and high tide falls into the class II category with a degree of acidity $(\mathrm{pH})$ 6-7 which means that Sungai Jingah water is acidic.

\subsection{TDS (Total Dissolved Solids)}

The content of physical parameters, namely TDS (Total Dissolved Solids) in the Sungai Jingah at low tide and high tide indicates that all segments are in the class I category (100). Total content of TDS (Total Dissolved Solids) at low tide in segment IVB (80 ppm (mg / 1)), segment VB (80 ppm $(\mathrm{mg} / \mathrm{1})$ ), segment IA (80 ppm (mg / 1)), and segment IIB $(50 \mathrm{ppm}(\mathrm{mg} / 1))$. The TDS content at high tide is in segment IVB (60 ppm (mg / 1)), segment VB (60 ppm (mg / 1)), segment IA (50 ppm (mg/ 1)), and segment IIB (50 ppm (mg / 1)). Based on the Regulation of the Governor of South Kalimantan Number 5 of 2007, the results of TDS (Total Dissolved Solids) obtained in all segments in the Sungai Jingah at low tide and high tide fall into the class I category (100). The low TDS (Total Dissolved Solids) content indicates that the water quality is still good.

\subsection{Community behavior on the banks of the Sungai Jingah, Banjarmasin City}

Most of the people on the banks of the Sungai Jingah have latrines on the banks of the river, in addition, the river is a landfill for sewage. Disposal of sewage into the river causes the river to become increasingly polluted, resulting in a decrease in river water quality. The results show that there has been an increase in public awareness not to throw garbage in the river, this is supported by the availability of waste transportation services for the community so that throwing garbage in the river is rarely done. People who do not use garbage collection services will usually throw garbage in a place that has been provided or burn it.

Most of the people on the banks of the Sungai Jingah no longer use Sungai Jingah water for drinking water consumption. The community prefers to buy refill drinking water that is widely available in the vicinity of the community's residents.

\subsection{Use of rivers for Toilet activities}

The results showed that most of the people on the banks of the Sungai Jingah did not use Sungai Jingah water for their daily activities such as bathing, washing clothes, and washing dishes. People who do not use Sungai Jingah water for their daily activities are because they have subscribed to PDAM water. The results also show that there are still a small part of the people on the banks of the Sungai Jingah who use Sungai Jingah water for 
their daily activities, generally, people who use Sungai Jingah water are people who have not subscribed to PDAM water but some have subscribed but to save on the cost of paying PDAM water they also sometimes use river water. Sungai Jingah water that can be used for bathing, washing clothes, and washing dishes is water which is in high tide because its quality is cleaner than river water at low tide.

\section{CONCLUSION}

The content of Fecal Coliform bacteria in the Jingah River at low tide and high tide is at the maximum threshold above class I so that Jingah River water cannot be used for drinking water sources. The BOD content in class I, II, and III indicates that the BOD content is still low. The $\mathrm{pH}$ content in the Jingah River is included in class II, namely a pH of 6-7 (acid). The TDS content of Jingah River at low tide and high tide is in the class I category (100). The significant value of the relationship between Fecal Coliform There is no correlation between Fecal Coliform with BOD, $\mathrm{Ph}$, and TDS because the significant value exceeds $(>0.05)$. Most of the people on the banks of the Jingah River do not use Jingah River water for drinking, bathing, washing clothes, washing dishes, and other activities.

\section{REFERENCES}

[1] D. Biyatmoko, "Potensi Beban Pencemar (Pbp) Air Asal Limbah Peternakan di Kota Banjarmasin," EnviroScienteae, vol. 8, no. 1, pp. 23-29, 2016.
[2] L. J. Bao, K. A. Maruya, S. A. Snyder, and E. Y. Zeng, "China's water pollution by persistent organic pollutants," Environ. Pollut., vol. 163, pp. 100-108, 2012.

[3] BPS Kalimantan Selatan. Banjarmasin dalam Angka. Banjarmasin: BPS, 2010.

[4] BPS Kota Banjarmasin. Kota Banjarmasin dalam Angka. Kota Banjarmasin: BPS, 2018.

[5] C. Khairunnisa, Pengaruh Jarak dan Konstruksi Sumur serta Tindakan Pengguna Air terhadap Jumlah Coliform Air Sumur Gali Penduduk di Sekitar Pasar Hewan Desa Cempeudak Kecamatan Tanah Jambo Aye Kabupaten Aceh Utara Tahun 2012. Tesis. Fakultas Kesehatan Masyarakat Universitas Sumatera Utara. 2012.

[6] Ercumen, A., Pickering, A. J., Kwong, L. H., Arnold, B. F., Parvez, S. M., Alam, M., ... \& Ahmed, R. Animal feces contribute to domestic fecal contamination: evidence from E. coli measured in water, hands, food, flies, and soil in Bangladesh. Environmental science \& technology, 51(15), 8725-8734, 2017.

[7] S. Khotimah, Kepadatan Bakteri Coliform di Sungai Kapuas Kota Pontianak. Jurnal Prosiding Semirata FMIPA Universitas Lampung, 2013.

[8] R. Melliawati, Escherichiasacoli dalam Kehidupan Manusia. BioTrends Vol. 04 No. 1:210-14, 2009.

[9] Rachmadi. Pembaharuan Hukum Lingkungan Nasaional. Penerbit PT Citra Aditya Bakti. Bandung, 2001.

[10] U. Suriawira. Mikrobiologi Air dan Dasar-Dasar Pengolahan Secara Biologis. Bandung: Angkasa, 2008. 